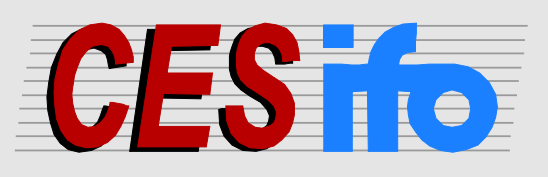

\title{
Working
}

Papers

www.cesifo.org/wp

\section{Economic Growth in Africa: Comparing Recent Improvements with the "lost 1980s and early 1990s” and Estimating New Growth Trends}

\author{
Willi Leibfritz \\ Gebhard Flaig
}

\author{
CESIFO WORKING PAPER NO. 4215 \\ CATEgory 6: Fiscal Policy, MaCROECONOMICS AND GROWTH \\ APRIL 2013
}

An electronic version of the paper may be downloaded

- from the SSRN website:

- from the RePEc website:

- from the CESifo website:

wWw.SSRN.com

www.RePEc.org

www.CESifo-group.org/wp

\section{CESifo}




\title{
Economic Growth in Africa: Comparing Recent Improvements with the "lost 1980s and early 1990s” and Estimating New Growth Trends
}

\begin{abstract}
In the first part of the paper we look at economic growth in Africa over the past three decades. We divide the past three decades into two parts: A „lost period“ from 1981 to 1995 and a „recovery period“ since the second half of the 1990s. During the first period, Africa did not catch up but lost ground, Africa's average per capita income declined. Since the mid-1990s the continent started to catch-up. The boom in the oil price and other raw material prices during the past decade explains only part of this rebound. Many countries also benefited from greater political stability and economic reforms. Although the improved growth performance has helped to improve human development and reduce poverty, poverty levels remain high in many countries and more needs to be done to make growth more "inclusive".

In the second part we estimate the trend growth rates for Africa and several individual countries. We use the Hodrick-Prescott filter with different values for the smoothing parameter $\lambda$. For some countries we specify time-varying values for $\lambda$ in order to model breaks in the level and the growth rates of GDP trend. For Africa as a hole and for most countries we find relatively low trend growth rates until the mid-nineties. Since then the trend growth rates rose remarkably - for Africa from $2 \%$ to about $5 \%$. In the last five years we observe a slight decrease to about $4 \frac{1}{2} \%$.
\end{abstract}

JEL-Code: O550, C220.

Keywords: Africa, growth, trend, HP filter.

Willi Leibfritz

Fritz-Lutz-Strasse 4

Germany-81929 Munich

willi.leibfritz@web.de
Gebhard Flaig

LMU Munich

Schackstrasse 4

Germany - 80539 Munich

gebhard.flaig@lrz.uni-muenchen.de 


\section{Introduction}

In recent years Africa's economies have rebounded. This has raised hopes that - at last - this continent could also catch up similar as Asian economies. People are talking about "Lions on the move" (McKinsey Global Institute, June 2010) and the World Bank states "Africa could be on the brink of an economic take-off, much like China was 30 years ago and India 20 years ago." (World Bank, 2011). However, others are more sceptical and point to remaining problems such as political uncertainty, corruption and poverty. The sceptical views are supported by newspaper articles, which tend to focus on problem cases rather than on success stories, as "only bad news are good news". Given the large differences between individual countries it is indeed difficult to assess Africa's overall economic performance. It is true that the three largest economies, South Africa, Egypt and Nigeria, produce around $45 \%$ of Africa's Gross Domestic Product. And if one adds the following seven largest economies (Algeria, Morocco, Angola, Tunisia, Libya, the former unified Sudan and Ethiopia) these ten economies produce three quarters of Africa's GDP. Although the other 44 countries produce only one quarter of Africa's GDP, their population amounts to 500 million, or almost half of the continent's population. The economic and social development in these smaller countries is therefore also very important for the welfare of many people in Africa.

This paper takes a closer look at economic growth in Africa over the past three decades. In the first part it describes Africa's growth performance over time and discusses some possible explanations for its recent improvement. In the second part an attempt is made to identify for several countries how much of the improved growth performance has been caused by cyclical effects and how much by higher trend growth. For this aim we estimate for Africa and several individual countries trend growth rates using the Hodrick-Prescott filter.

\section{Africa's growth performance over the past three decades ${ }^{1}$}

The past three decades can be divided into two parts: A „lost period“ from 1981 to 1995 and a „recovery period“ since the second half of the 1990s.

\subsection{The "lost" period of the 1980s and early 1990s}

From 1981 to 1995 Africa's annual average GDP growth (in constant prices) amounted to only $2.3 \%$. It was much less than growth of world GDP so that Africa did not catch up but lost ground (Figure 1). Africa's GDP growth was also lower than population growth $(2.7 \%)$ so that the average income level of the continent as measured by Africa's per capita GDP declined. It was in 1995 almost 7\% lower than in 1980. The 1980 level had already been very low and should - according to growth theory - have helped Africa's catching-up.

At the same time Africa's income inequalities as measured by the Gini-coefficient increased. This was due to both a deterioration of inequality across countries (as richer countries grew faster than poorer countries) and more inequality within countries (while the rich stayed rich or became even richer, poorer people became poorer). By 1995 one of every two African

\footnotetext{
1 This part draws to some extent on Leibfritz (2012).
} 
citizens lived in poverty and in sub-Saharan Africa the poverty rate amounted even to $60 \%$ (Artadi and Sala-i-Martin 2003).

In African countries with below average GDP growth per capita GDP had declined even more than the above-mentioned 7\%. In Liberia per capita GDP had collapsed in 1995 to one tenth of the 1980 level. In Libya it had declined by more than half, in Sierra Leone by more than $40 \%$, in Angola by one third, in the Democratic Republic of Congo and in Côte d'Ivoire by $30 \%$, in Somalia and Rwanda by a about one quarter, in Ethiopia and Mozambique by around one fifth, in South Africa by around $15 \%$ and in Algeria by more than a tenth. One explanation for this dismal growth performance was that many of these countries had been hit by political conflicts, including civil wars or regional rebellions (such as Algeria, Angola, Congo Dem. Rep., Liberia, Mozambique, Rwanda and Somalia) or suffered from economic sanctions and/or misguided economic policies (such Libya until 1994 and the apartheid regime in South Africa until 1994).

However, even during this „lost period“ of Africa a few countries still recorded relatively high GDP growth (such as Botswana and Mauritius) and increasing levels of per capita income.

Figure 1. Average GDP growth in Africa and in the global economy (in \%)

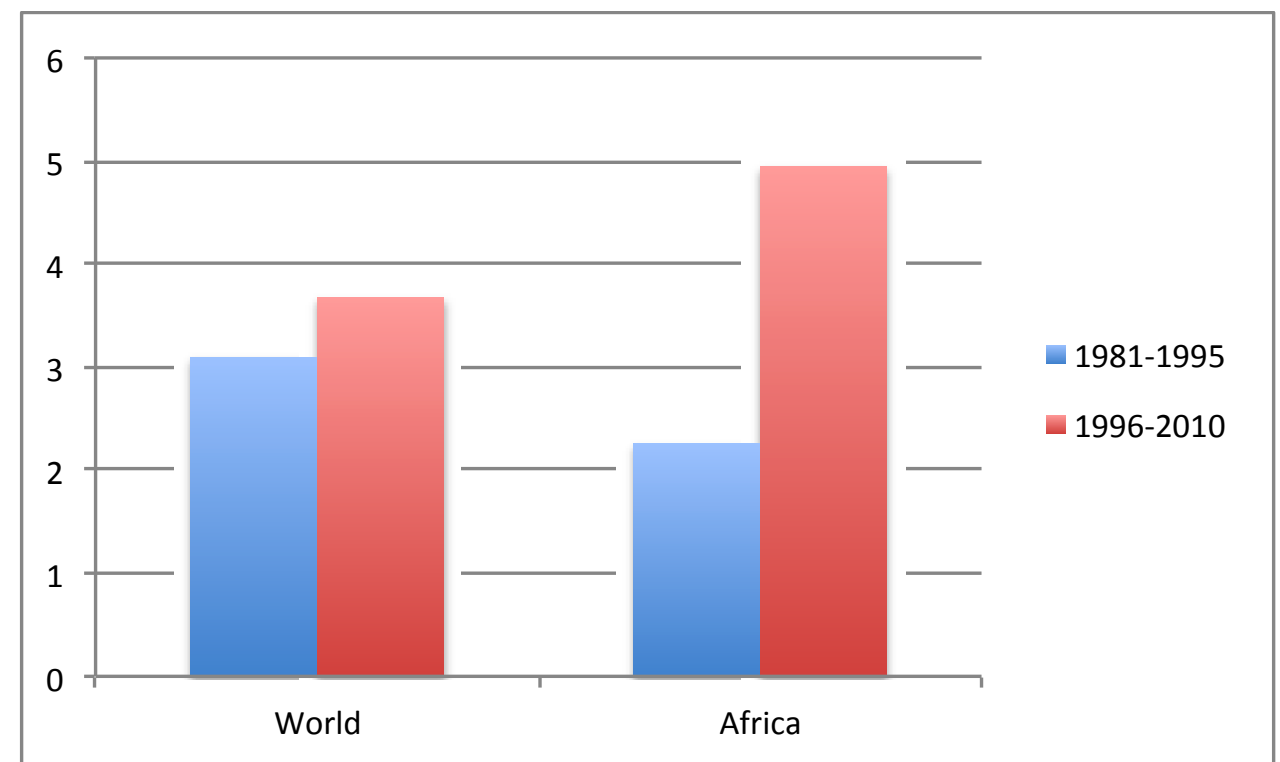

Source: International Monetary Fund, African Development Bank, authors' calculations.

\subsection{The catching-up since the mid-1990s}

Since the „lost“" 1980s and early 1990s Africa's economic performance improved significantly and the continent started to catch-up. From 1996 to 2010 Africa's annual average GDP growth amounted to close to 5\% and was significantly higher than growth of world GDP (3.7\%). Africa's GDP growth was also higher than population growth $(2.3 \%)$ and per capita GDP increased on average during this period year by year by $2.5 \%$. As a result Africa's average level of per capita income was in $201046 \%$ higher than in 1995. 
Figure 2. Comparing GDP growth in African countries between the periods 1981-1995 and 1996-2010 (average annual growth in \%)

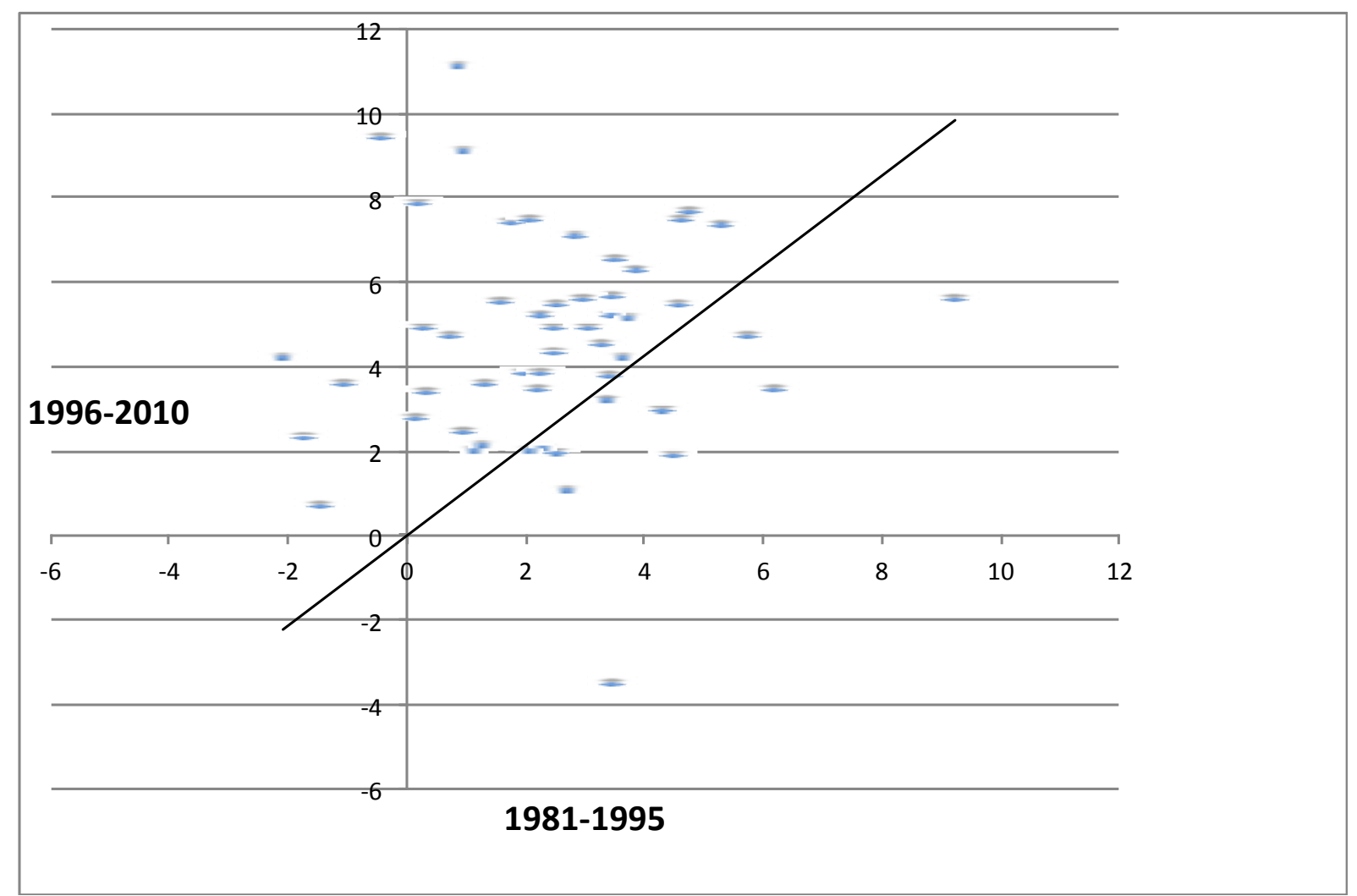

Source: African Development Bank, authors' calculations.

Figure 3. Oil price developments

(Average of three spot prices in US Dollars per barrel)

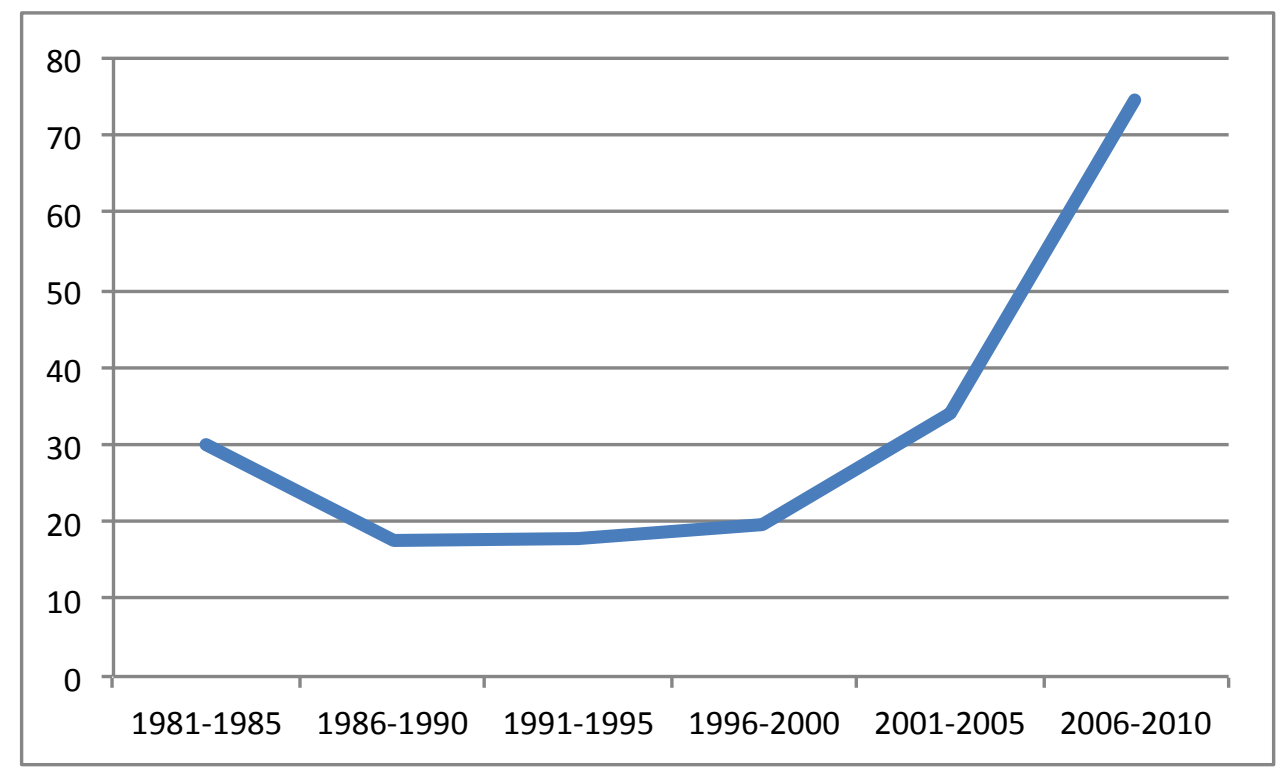

Source: International Monetary Fund.

The catching-up of African economies since the mid-1990s has been widespread. This is also illustrated in Figure 2. Individual countries' growth before and after the mid-1990s are 
marked as points and most of these are above the $45^{\circ}$ line, which shows that in most countries growth was higher after the mid-1990s than before. The boom in the oil price and other raw material prices during the past decade explains only part of this rebound. The main beneficiaries were oil-exporting countries such as Nigeria, Angola, Libya and Sudan (before the separation in 2011). Other countries, which largely depend on other raw materials also benefited from higher commodity prices, such as Zambia, which is a major exporter of copper or Botswana, which depends on exports of diamonds. But also countries which are less dependent on commodities and which suffered terms of trade losses due to higher oil prices were able to achieve higher growth. These countries benefited from greater political stability and economic reforms. This is particularly true for Rwanda, which recovered from the genocide in 1994 and was in 2010 praised by the World Bank as the best economic reformer of the world. South Africa, which is the largest economy in sub-Saharan Africa and belongs together with Egypt also to the two largest economies of the continent, benefited from the end of apartheid with the end of economic sanctions. Growth accelerated reaching above 5\% before the international financial crisis in 2008/2009. With an economy more integrated with international financial and product markets South Africa fell into recession in 2009 but recovered again in 2010/2011. In Western Africa Ghana also attained a higher growth thanks to better economic policies and - more recently - the exploitation of new oil reserves.

Although Africa's growth performance has clearly improved since the mid-1990s there is much room for further improvements. Barriers to growth continue to exist in large parts of the continent, notably infrastructure bottlenecks (insufficient and unreliable energy, poor transport system), lack of skilled workers, red tape, corruption and underdeveloped financial sectors.

While political conflicts have declined since the 1980s and early 1990s the continent has not remained untroubled. Civil wars (Liberia 1999 to 2003, Congo Dem. Rep. 1998 to 2003, Côte d'Ivoire 2002 to 2007) and post-election conflicts (Côte d'Ivoire 2011, Kenya 2007/2008) disrupted the economies temporarily. The economy of Zimbabwe suffered a long-lasting depression due to a disastrous policy of President Mugabe with real GDP declining by around $60 \%$ between 1999 and 2008. The most recent example for political conflicts is the Arab Spring with revolutions in Tunisia, Egypt and Libya. In Tunisia and Egypt political unrest and insecurity affected in particular tourism and investment. In Tunisia GDP decline by around 2\% in 2011 and in Egypt growth was slashed from above 5\% to below 2\%. In Libya, the war brought oil production to a temporary halt and GDP declined in 2011 by around $60 \%$.

These revolutions had large short-term effects on the economies but with the overthrow of the autocratic regimes they also open the way for a better use of growth potentials and more equal income distribution. Preconditions are, however, that political stability and security is restored, that transparent democratic institutions are created and that countries succeed in reducing the high youth unemployment, which had led to the outbreak of these revolutions.

Political conflicts continue to bedevil also other African countries (such as Somalia and most recently the conflicts in Mali and between Sudan and South Sudan) but these are exceptions and not the rule on a continent, which consists of 54 countries.

Africa's improved growth performance has also helped to improve human development as measured by the Human Development Index HDI of the UN. This index is combining indicators of life expectancy, educational attainment and average income. Africa's average HDI increased between 1990 and 2000 by $4.5 \%$ and between 2000 and 2011 by $12.5 \%$ (AfDB et al. 2012). Higher growth after the mid-1990s has also helped to reduce poverty. Before 
Africa's average poverty rate has increased but this trend reversed after a peak in 1996 at almost 50\%. However, the pace of poverty alleviation was moderate and by 1997 (the latest year available for this comparison) Africa's average poverty rate was still above $40 \%$ (AfDB et al. 2010). Higher growth appears to have helped poverty to decline but the low pace suggests that the elasticity of poverty to growth is relatively low. Indeed, various studies found this elasticity to be lower in sub-Saharan Africa than in other developing regions (Besley and Burgess 2003, Fosu 2009, Kalwij and Verschor 2007). The obvious reason that in many African countries growth is less ,,inclusive“ i.e. large parts of the population do not or do only little benefit from growth while political and economic elites enrich themselves and reap most of the benefits. This is a particular problem in Africa's oil-exporting countries ${ }^{2}$ but it exists also in several other countries. Africa's challenge therefore is not only to sustain a high growth path but also to make growth more inclusive. This would significantly improve welfare of African people and would also reduce political tensions thus improving political stability of countries, which is a precondition for sustained economic growth. For example, Acemoglu and Robinson (2012) show, how in Botswana inclusive political institutions have developed historically and have bred political stability and supported inclusive economic institutions. From this perspective it should come as no surprise that Botswana is one of the very few African countries, which achieved sustained growth during a very long time. While other countries struggled during the 1989s and early 1990s, average growth in Botswana above $9 \%$ and growth was also sustained since then at an average rate of above 5\%. It is true that Botswana's growth is boosted by diamond exports. But while many other resource-rich countries fell into the "natural resource trap" with malfunctioning democracy and the "survival of the fattest" (Collier, 2008), the inclusive political and economic institutions have saved Botswana from this trap and have ensured that its resource wealth is managed quite well with revenue used to provide public services and to save part of it for the future.

In the following we estimate for several countries the underlying growth trend. By eliminating purely cyclical effects from annual growth one can better assess how much of the recently improved growth performance has been due to more fundamental factors, thus being more likely to be sustained.

\section{Estimating trend growth for selected countries}

\subsection{Methodology}

In the following we use the Hodrick-Prescott filter (Hodrick/Prescott, 1997) for the estimation of trend growth rates for Africa and several individual countries. The most crucial point is to select an appropriate value for the smoothing parameter $\lambda$. Based on assumptions concerning the signal-to-noise ratio (the ratio between the variance of the second differences of the trend to the variance of cyclical component), Hodrick/Prescott (1997) suggest for quarterly data a value of 1600 for $\lambda$ and for yearly data a value of 100 . Ravn/Uhlig (2002) argue on the basis of arguments in the frequency domain that for yearly data $\lambda$ should be in the range between 6 and 7 (under the assumption that

\footnotetext{
${ }^{2}$ For example, Angola has achieved high GDP growth largely driven by oil exports. But, according to the African Economic Outlook (2012) it also belongs to the most unequal societies in the world with a Gini coefficient of 0.586 .
} 
$\lambda=1600$ is optimal for quarterly data). However, Flaig (2012) shows that in the plausible case of an autocorrelated cyclical component the parameter $\lambda$ should be much higher than the inverse signal-to-noise ratio. In our empirical analysis we are somewhat agnostic and present estimates of trend growth rates for $\lambda$ equal to 6.7, 100 and (as a compromise) for $\lambda=30$.

Another problem concerns sudden jumps in the level or the first difference of the trend component of a time series. Using the standard HP filter, such jumps are smoothed away. The estimated trend value is higher than the true value in periods before the jump occurs and lower thereafter (assuming a positive jump, the reverse holds for a negative jump). We can adopt the HP filter to this situation by allowing time-varying values for $\lambda$. For instance, when we assume a jump in the growth rate of the trend in a specific period, we could set $\lambda$ to a relatively low value in that period. We then get a jump in the estimated growth rate of the trend and a kink in the level series. When we suspect a jump in the level of the trend, we should set $\lambda$ to a low value in the respective and in the next period (Pollok, 2009; Razzak/Dennis, 1995).

The input for the HP filter is the log-value of real GDP. The level was calculated by setting the start value in 1980 to 1 and then accumulating the growth rates, provided by the African Development Bank for 1980 to 2013. The values for 2012 and 2013 are forecasts. In the following results we show for the trend growth rates only values until 2012.

\subsection{Empirical results}

The following figures show for Africa and for several selected individual countries the actual growth rates of real GDP (dashed black line with solid squares) and the estimated trend growth rates for different values of the smoothing parameter of the HP filter. For all countries, we use three different values for $\lambda: 6.7,30$ and 100 . The higher the value of $\lambda$, the smoother the generated trend and therefore the trend growth rates. For some countries we use timevarying values in order to capture sharp jumps in the level or the growth rate of the trend.

Figure 4: Africa (all countries)

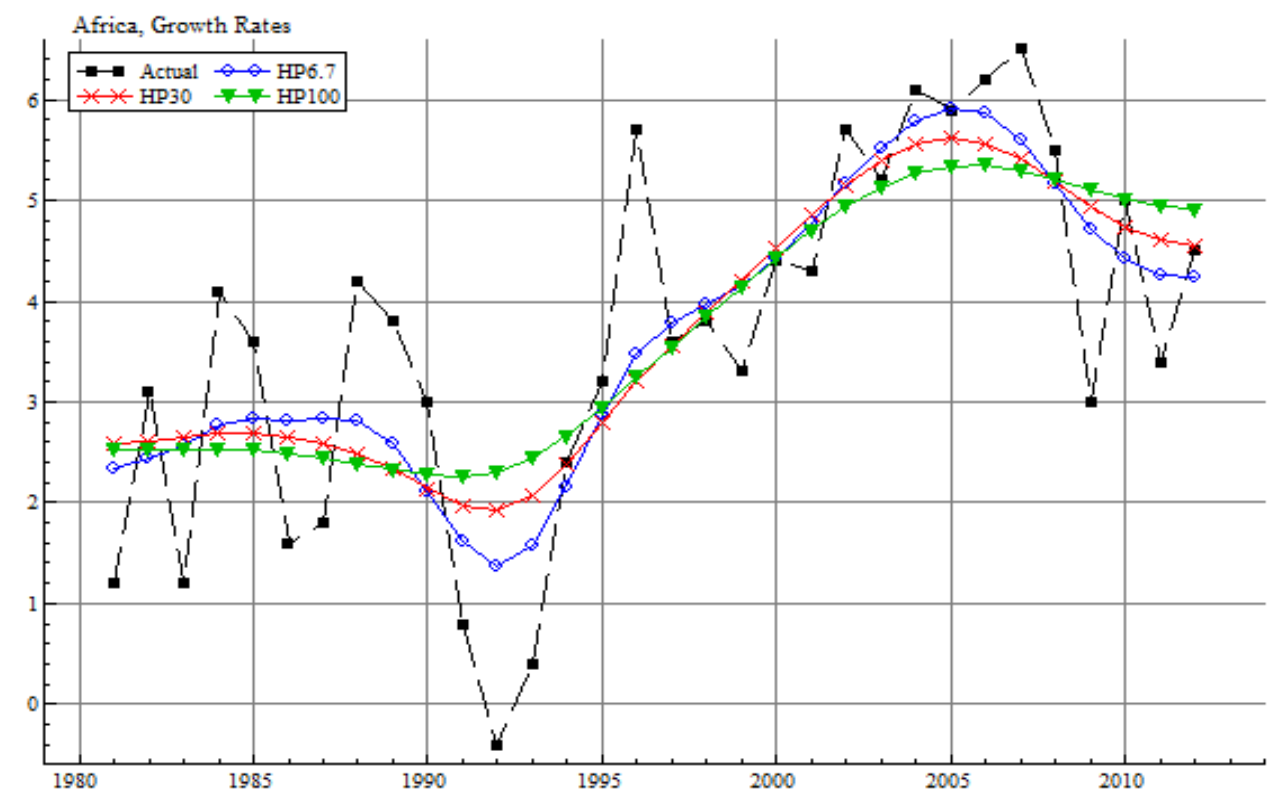


Figure 4 presents the results for Africa. In the interpretation of this and the following figures we refer in most cases to the trend growth rates generated by using a value of 30 for $\lambda$ (red line with crosses). From 1980 to about 1992, the trend growth rate was approximately $2 \frac{1}{2} \%$. From 1993 to 2006 there was a steady increase in the trend growth rate to about $5 \frac{1}{4} \%$, thereafter a slight decrease, triggered especially by relatively low growth rates in 2009 and 2011 (even in these two years the actual growth rate of GDP was higher than 3\%). The estimated value for the trend growth rate in 2012 is about $4 \frac{1 / 2}{\%}$. This is twice as much as in the first part of the 1990s.

We now turn to the five largest individual countries, measured by GDP: South Africa, Egypt, Nigeria, Algeria and Morocco. From 1981 to 1993 \% (the end of the Apartheid) the trend growth of South Africa real GDP was slightly higher than 1\%. From then it increased to $4 \%$ in the year 2005. Thereafter we estimate a decrease to a value of about $2.8 \%$ in the year 2012 (Figure 5).

Figure 5: South Africa

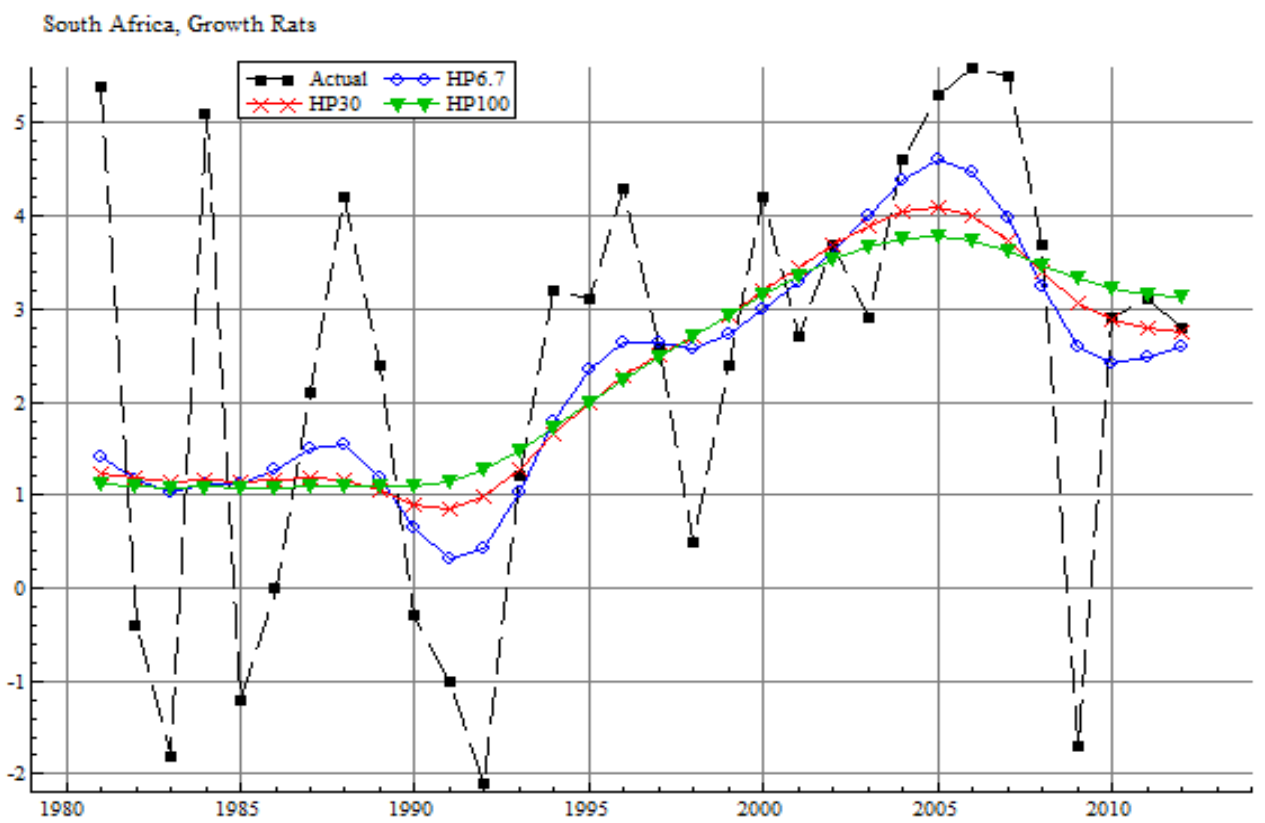

After the end of the Apartheid, one observes a remarkable increase in the mean growth rates of GDP. Therefore, we allow for a jump in the trend growth rate and model this by setting $\lambda$ in the year 1994 to a value of 6 . In all other years the smoothing parameter $\lambda$ was set to 30. The result is shown in figure 6. From 1980 to 1990 and from 2000 onwards the estimated trend growth rates are the same as in the standard procedure. In the years 1991 to 1993 the values are slightly lower, in the years 1994 to 1997 slightly higher. In the year 1994 we estimate a sudden jump in the trend growth rate in the order of one percentage point. 
Figure 6: South Africa (HP30; Jump in the trend growth rate in 1994)

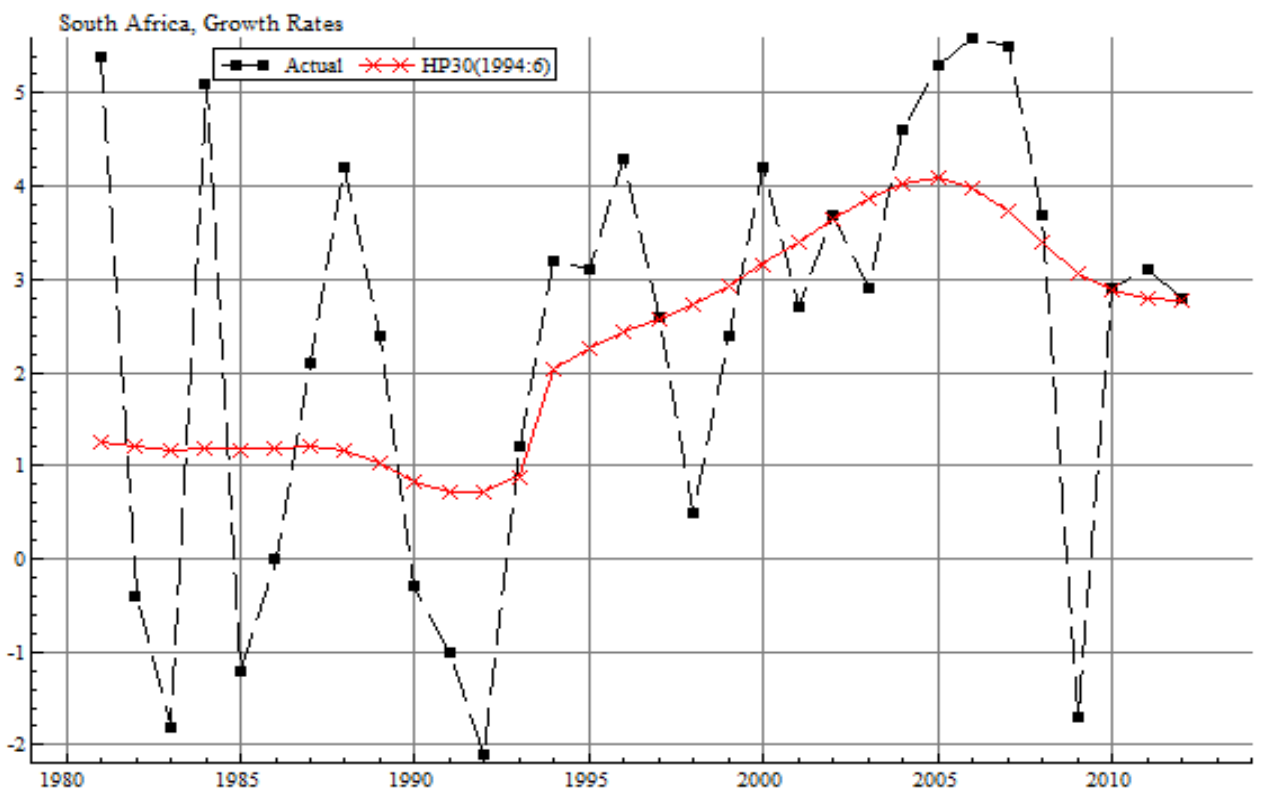

Figure 7 shows the results for Egypt, the second largest countries in Arica, measured by GDP. The trend growth rate shows a decline from $6.3 \%$ in 1981 to $3.5 \%$ in the year 1992 and then an increase to about $5.2 \%$ in 2002. The relatively low actual growth rates of GDP in the last four years (2009 to 2012) lead to a decline in the trend growth rate to about $4 \%$ in the year 2012. Due to the political events it is very difficult to determine the actual trend growth rate with some confidence.

Figure 7: Egypt

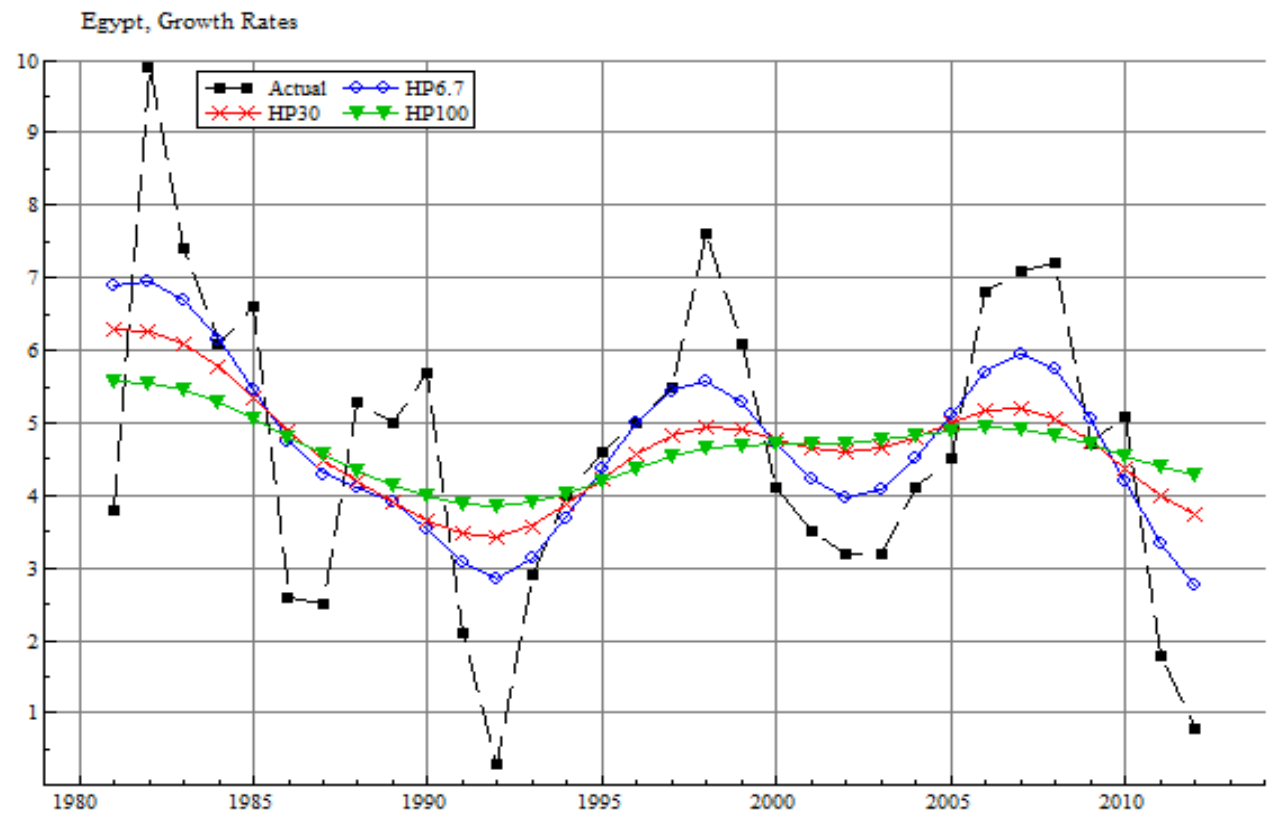


Nigeria started in the early eighties with a trend growth rate lower than $1 \%$ (see figure 8). One observes then a more or less steady increase to about $9 \%$ in the years 2002 to 2004, thereafter a slight decrease to $6.8 \%$ in the year 2012 .

\section{Figure 8: Nigeria}

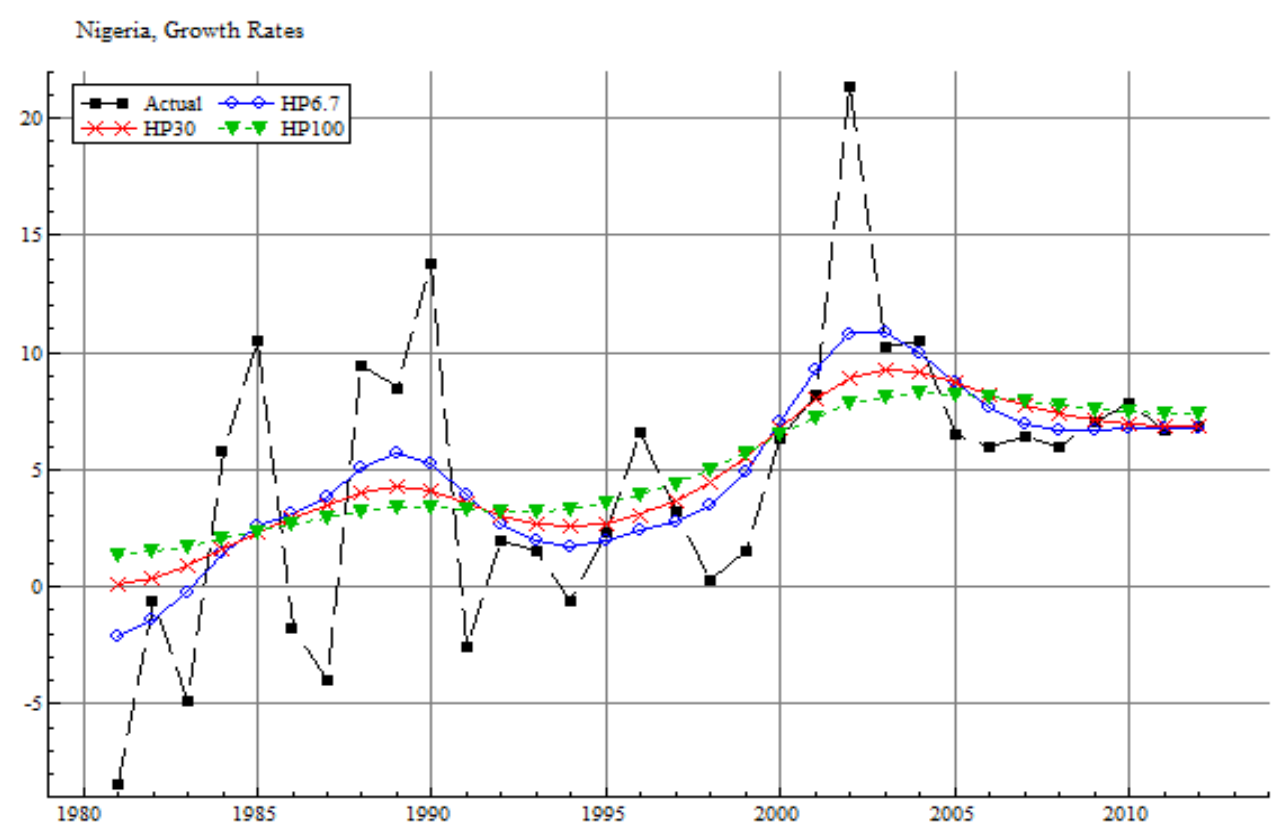

In Algeria, the trend growth rate declined from $4 \%$ in the early eighties to $1 \%$ in the mid-nineties (see figure 9). Then a steady acceleration is observed with a peak of somewhat more than $4 \%$ in the years 2002 to 2004, thereafter a decline to $3 \%$ at present.

Figure 9: Algeria

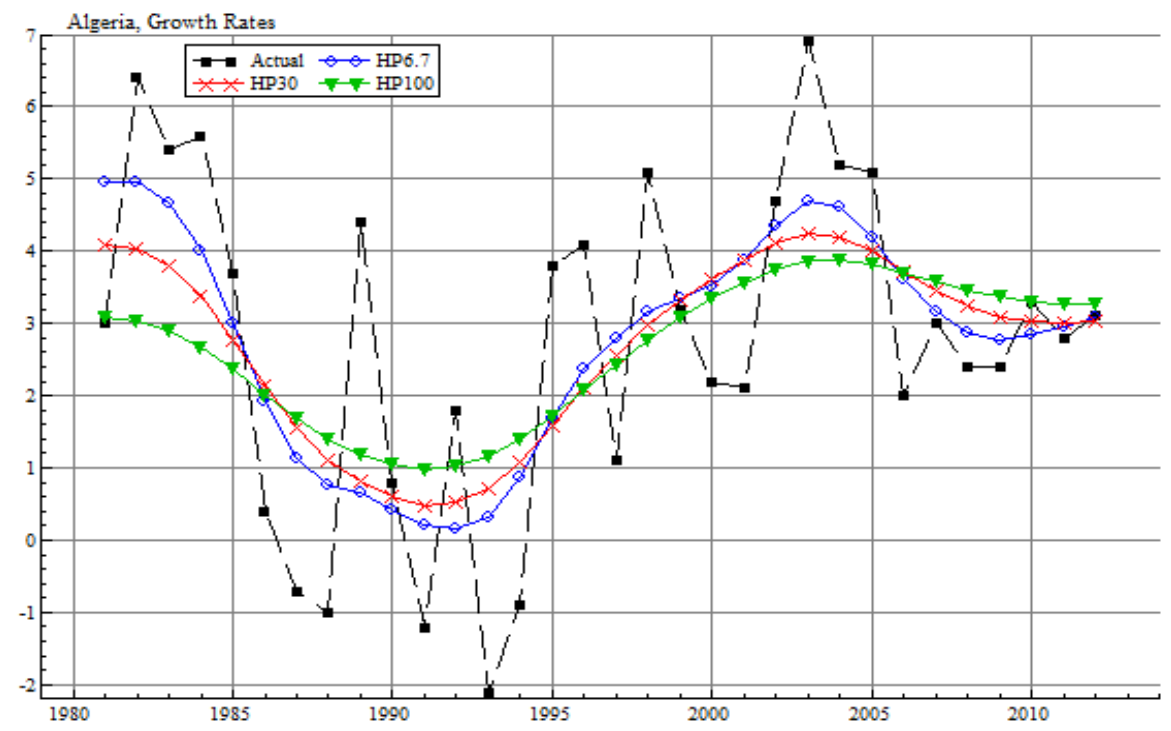


In the last two decades of the last century, the growth rates of GDP in Morocco were very volatile (see figure 10). As in many other African countries, the trend growth rate was declining until 1995 from about $4 \%$ to $2.3 \%$. Then we estimate an acceleration to a peak of $4.8 \%$. At present (2012), the estimated growth rate is $4.5 \%$.

Figure 10: Morocco

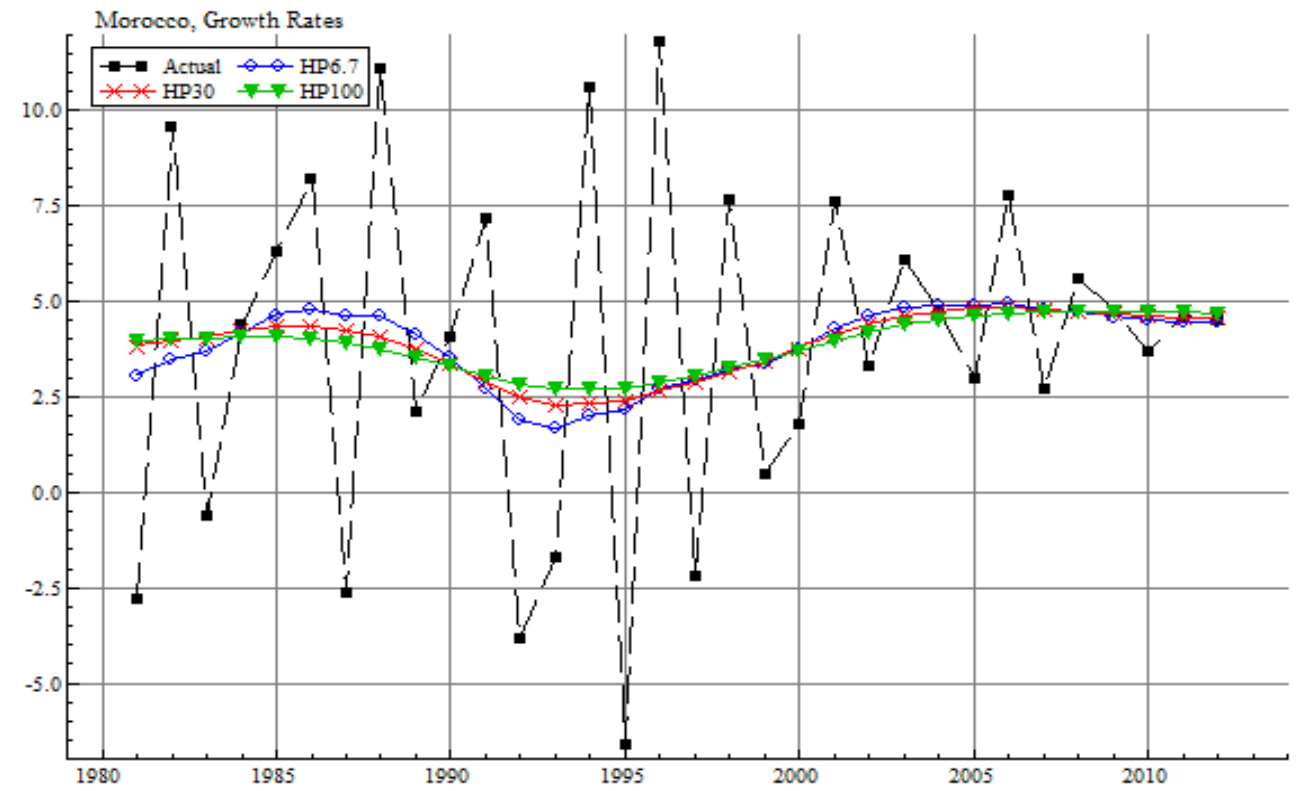

In order to illustrate the possibility to model sharp changes in the trend growth rates by using time varying values of the HP smoothing parameter, we show the results for the countries Liberia and Congo (DR).

In Liberia, the HP-estimated trend growth was negative until 1995 (see figure11). Since then the trend growth rates generated by using the values 30 and 100 for the HP smoothing parameter where positive, with an estimated value of about $5 \%$ at the end of the sample. A closer look on the actual growth rates reveals that we have a very sharp drop in the year 1989 . From 1989 to 1994 we have growth rates in the range between -10 to $-50 \%$ ! We try to capture these sharp jumps by using time-varying values of the smoothing parameter. We assume a break in the trend growth rates in 1989 and 1996 and a level break in 2003 and set $\lambda$ equal to the very low value of 3 in the years 1989 and 1996 and equal to 6 in the years 2003 and 2004 . In all other years $\lambda$ was set to 30 . Figure 12 shows the results. We have now a sharp drop in 1989 , due to a civil war. After the end of the civil war, the trend growth rate jumps from about $-20 \%$ to about $+25 \%$. Due to a second civil war the growth rate declined again. Since 2003 there is a slow recovery. The estimated trend growth rate in 2012 is about 5\%. 
Figure 11: Liberia

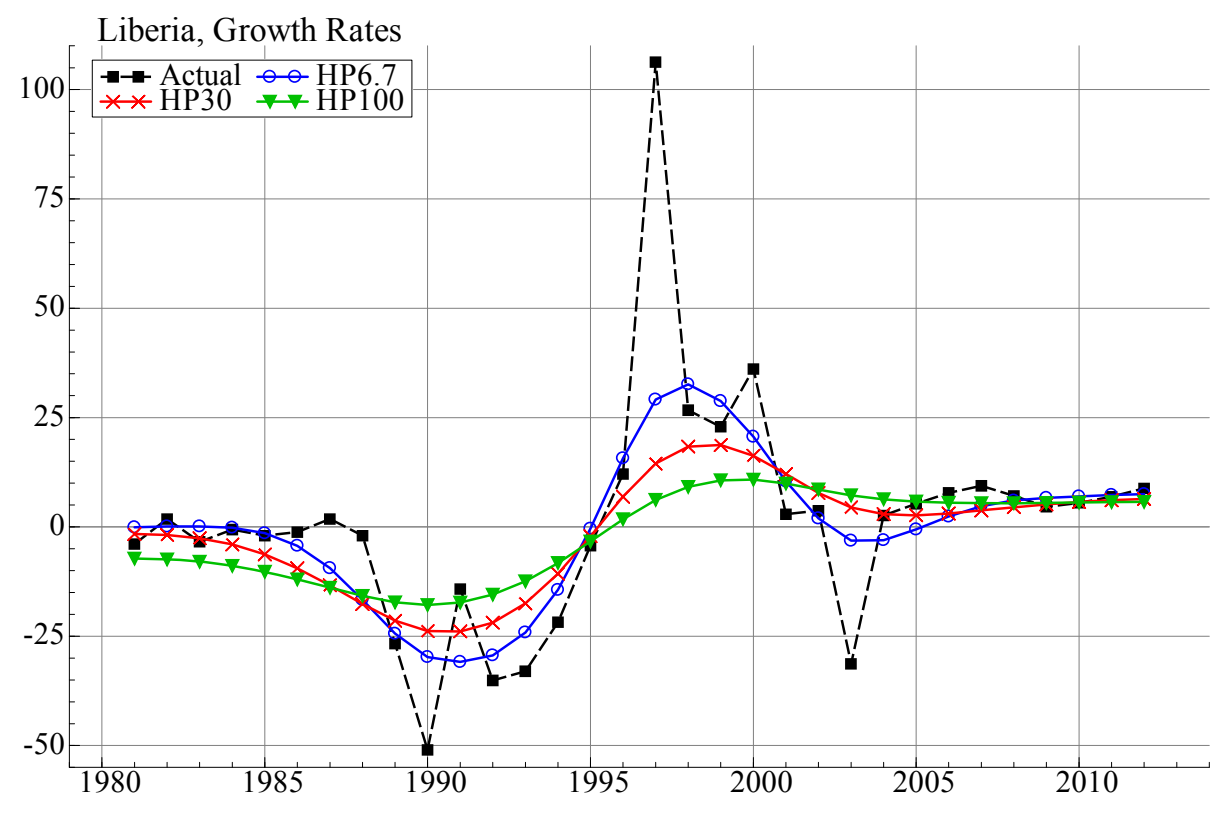

Figure 12: Liberia (HP30; Jump in the trend growth rate in 1989 and 1996 and a level break in 2003)

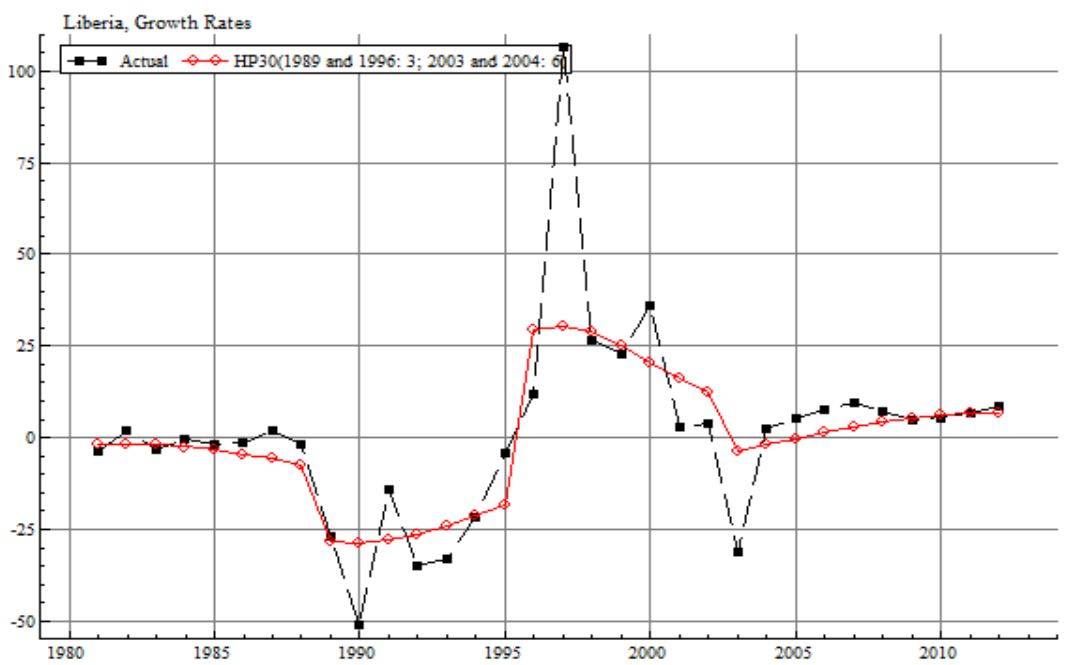

The Democratic Republic Congo has very volatile growth rates of GDP. In the first half of the eigthies the estimated trend growth rate (using for $\lambda$ the value of 30) was about $2 \frac{1 / 2}{2}$ $\%$. It then declined until the year 2000 to negative values. Since 2005 the estimated trend growth rate is about $6 \%$. 
Figure 13: Congo (DR)

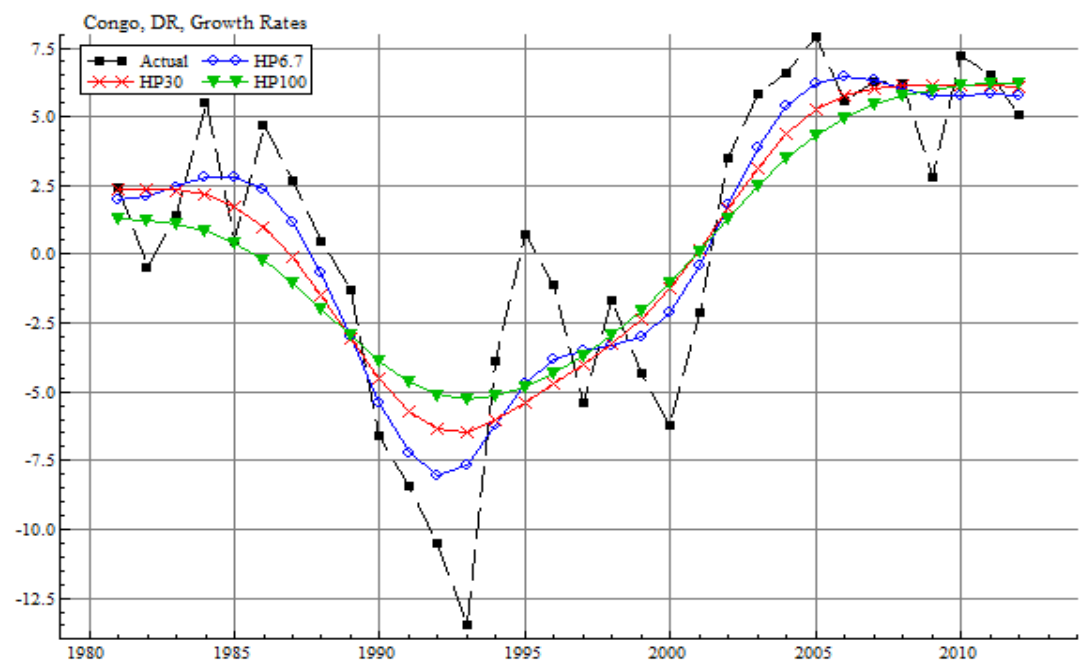

In order to get a clearer picture of the economic development we assume that in the years 1989, 1994 and 2002 jumps in the trend growth rate occur. We set $\lambda$ to a value of 3 in the mentioned years and to 30 in all other years (see figure 14).

Figure 14: Congo (DR) (HP30; Jump in the trend growth rate in 1989,1994 and 2002)

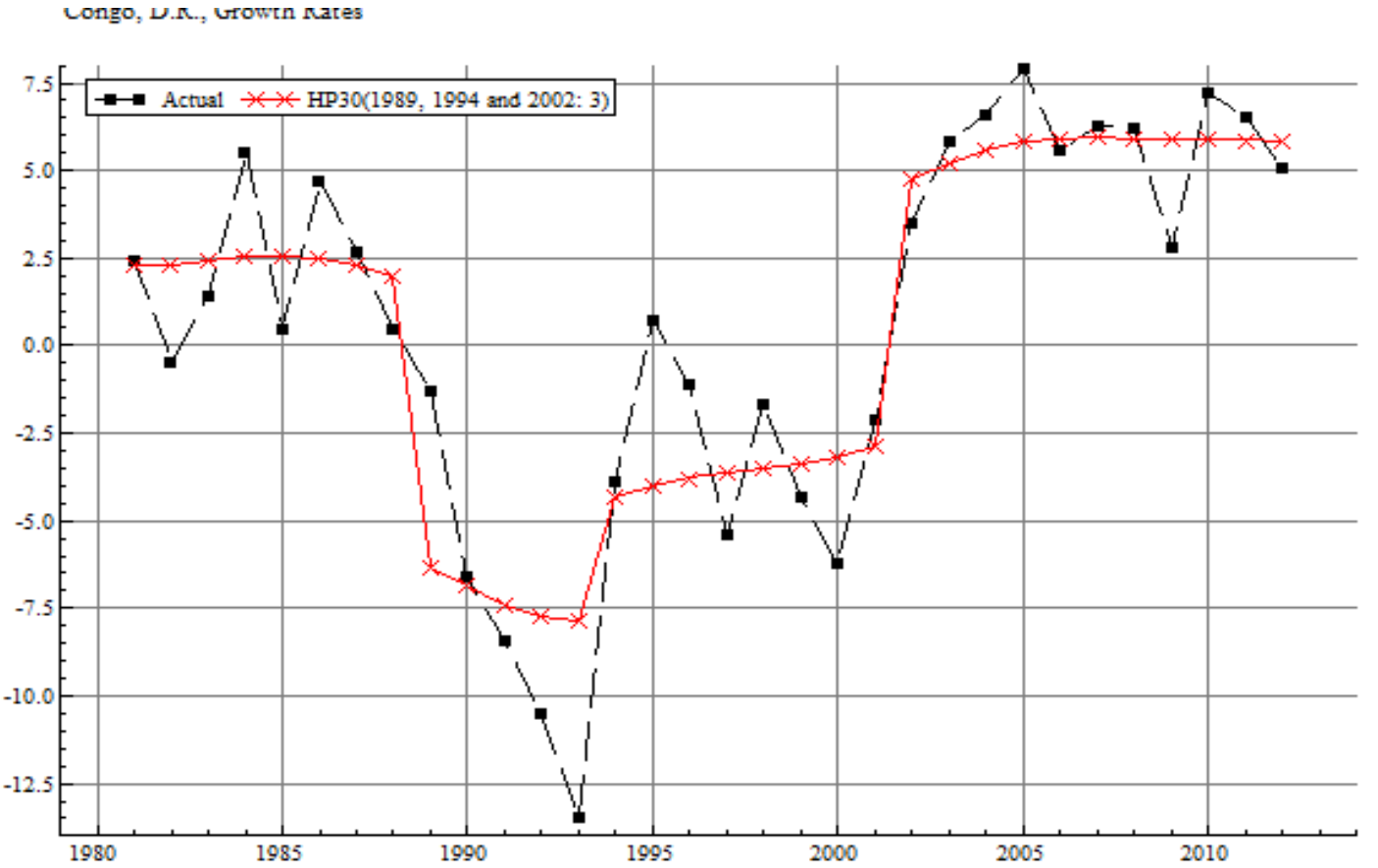

\section{Summary}

In the first part of the paper, we looked at economic growth in Africa over the past three decades. We divided the past three decades into two parts: A „lost period“ from 1981 to 1995 and a „recovery period“ since the second half of the 1990s. During the first period, Africa's average growth was lower than growth of world GDP so that Africa did not catch up but lost ground. It was also lower than population growth, so that the Africa's average per capita income declined. Since the mid-1990s the continent started to catch-up. Africa's GDP growth 
was also higher than population growth. As a result Africa's average per capita income is now around $50 \%$ higher than in the mid-1990s. The boom in the oil price and other raw material prices during the past decade explains only part of this rebound. Many countries also benefited from greater political stability and economic reforms. While political conflicts have declined since the 1980s and early 1990s the continent's economic growth has temporarily been adversely affected by political conflicts on some countries, such as most recently by the 2011 revolutions in North Africa. Barriers to growth continue to exist in large parts of the continent, notably infrastructure bottlenecks lack of skilled workers, red tape, corruption and underdeveloped financial sectors. Furthermore, although the improved growth performance has helped to improve human development and reduce poverty, poverty levels remain high in many countries and more needs to be done to make growth more "inclusive".

In the second part of the paper we estimated trend grwoth rates for Africa and several selected individual countries. In most cases we find a common picture: In the 1980s and the first half of the 1990s trend growth rates were relatively low and even slightly declining over time. About the year 1995 we estimate a change in the trend growth rates. They started to rise and reached a level amost twice as high as in the early 1990s. For Africa we estimate the trend growth rate in the year 2005 as somewhat higher than $5 \%$ and in the year 2012 as $41 / 2 \%$. The slump in the world economy after the financial crises had only a modest negative effect on trend growth rates and trend growth continues to be twice as much as in the first part on the 1990s.

\section{References}

Acemoglu, D. and J. Robinson (2012), "Why Nations Fail, The Origins of Power, Prosperity and Poverty", Crown Publishers, New York 2012.

AfDB, OECD, UNDP and ECA, “African Economic Outlook, 2010”.

AfDB, OECD, UNDP and ECA, “African Economic Outlook, 2012”.

Artadi, E.V. and X. Sala-i-Martin (2003), "The economic tragedy of the XXth century: growth in Africa", NBER Working Paper 9865.

Besley, T. and R. Burgess (2003), "Halving Global Poverty", Journal of Economic Perspectives, 17: 3, 3-22.

Collier, P. (2008), "The Bottom Billion - Why the Poorest Countries Are Failing and What Ca Be Done About It", Oxford University Press.

Flaig, G. (2012), "Why we should use high values for the smoothing parameter of the Hodrick-Prescott filter". CESifo Discussion Paper 3816

Fosu, A.K. (2009), "Inequality and the Impact on Growth on Poverty: Comparative Evidence for Sub-Saharan Africa", Journal of Development Studies, 45: 5, 726-45.

Hodrick, R. and E. Prescott (1997), "Postwar U.S. Business Cycles. An Empirical Investigation“. Journal of Money, Credit, and Banking, 29, 1-16. 
Kalwij, A. and A. Verschoor (2007), "Not by Growth alone: The role of the distribution of income in regional diversity in poverty reduction", European Economic Review, 51: 4, 80529.

Leibfritz, W.(2012), “Globales Wachstum: Trends und Herausforderungen”, in Wagner, A. and U. Heilemann, Empirische Makroökonomik und mehr, Festschrift zum 80. Geburtstag von Karl Heinrich Oppenländer, Lucius Verlag, Stuttgart 2012,

McKinsey (2010), "Lions on the move: The progress and potential of African economies", McKinsey Global Institute, June 2010).

Pollock, D.S.G. (2009), "Investigating Economic Trends and Cycles". In: Mills, Terence and Kerry Patterson (eds.), Palgrave Handbook of Econometrics. Volume 2: Applied Econometrics. Palgrave Macmillan. 243-307

Razzak, Weshah and Richard Dennis (1995), "Estimates of New Zealand's Output Gap Using the Hodrick-Prescott Filter with a non-constant Smoothing Parameter". Reserve Bank of New Zealand Discussion Paper G95/8.

Ravn, Morton and Harald Uhlig(2002), "On Adjusting the Hodrick-Prescott Filter for the Frequency of Observations“. Review of Economics and Statistics, 84:2, 371-376

World Bank (2011), “Africa's Future and the World Bank's Support to It”, p.4. 